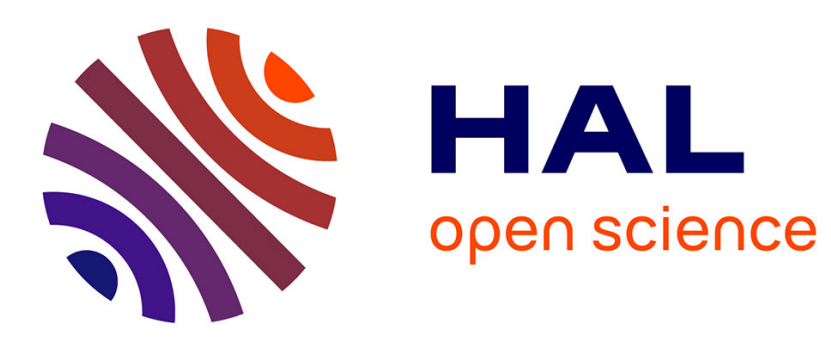

\title{
Is the emergence of new sovereign wealth funds a fashion phenomenon?
}

Jeanne Amar, Christelle Lecourt, Valerie Kinon

\section{To cite this version:}

Jeanne Amar, Christelle Lecourt, Valerie Kinon. Is the emergence of new sovereign wealth funds a fashion phenomenon?. Review of World Economics, 2018, 154 (4), pp.835 - 873. 10.1007/s10290-0180319-3 . hal-01897050

\section{HAL Id: hal-01897050 https://hal-amu.archives-ouvertes.fr/hal-01897050}

Submitted on 30 Apr 2019

HAL is a multi-disciplinary open access archive for the deposit and dissemination of scientific research documents, whether they are published or not. The documents may come from teaching and research institutions in France or abroad, or from public or private research centers.
L'archive ouverte pluridisciplinaire HAL, est destinée au dépôt et à la diffusion de documents scientifiques de niveau recherche, publiés ou non, émanant des établissements d'enseignement et de recherche français ou étrangers, des laboratoires publics ou privés. 


\title{
Is the Emergence of New Sovereign Wealth Funds a Fashion Phenomenon?
}

\author{
J. Amar ${ }^{\mathrm{a}}$, C. Lecourt ${ }^{\mathrm{b}, *}$, V. Kinon ${ }^{\mathrm{c}}$ \\ ${ }^{a}$ Aix-Marseille University, CERGAM EA 4225, 13540, Puyricard, France \\ ${ }^{b}$ Aix-Marseille University (Aix-Marseille School of Economics), CNRS \& EHESS \\ ${ }^{c}$ ICHEC Brussels Management School, Rue au Bois 365a, 1150 Brussels, Belgium
}

\begin{abstract}
The aim of the paper is to shed light on the question of why a country decides to set up a Sovereign Wealth Fund (SWF). Despite the recent financial crisis, 43 SWFs have been created between 2005 and 2014. In particular, we test if the emergence of these new recent funds can be explained by the following economic, political and institutional factors : i) the excess foreign exchange reserves due to natural resources rents or persistent current account surpluses; ii) the volatility of commodity prices; iii) a way to mitigate the "Dutch Disease" effect and iv) the governance of the country. We test these hypotheses on a sample of 37 countries that created a SWF over the period 2000-2014 and compare them to a large panel of countries that did not set up a SWF. In order to allow the temporal dimension as well as the unobserved heterogeneity between SWFs, a Logit panel model with random effects is estimated. The results show that countries for which the creation of a SWF is more appropriate are those with foreign exchange excess reserves, which are dependent on a commodity and on its volatility and which suffer from an appreciation of the real exchange rate. We also find that non-democratic countries with a high level of corruption are more likely to create a SWF. Our results may be of interest for policymakers debating whether or not it can be optimal for the country to establish a SWF.
\end{abstract}

Keywords : Sovereign Wealth Funds; Natural Resources Rents ; Country Factors ; Logit Panel Model

JEL classification : E21; E61; G23 ; F39; H59

*. Corresponding author.

Email addresses: jeanne.amar@iae-aix.com (J. Amar), christelle.lecourt@univ-amu.fr (C. Lecourt), valerie.kinon@ichec.be (V. Kinon) 
"Modern Sovereign Wealth Funds are not new. The first, the Kuwait Investment Office, was set up in 1953 just as Edmund Hillary and Tenzing Norgay were setting out to climb Mount Everest. The number of funds has been increasing since then like the traffic on the slopes of Everest" (John Gieve, former deputy Governor of Bank of England in a speech in London, 2008).

\section{Introduction}

May the constitution of a Sovereign Wealth Fund (SWF) be considered as a new phenomenon? Over the past decade, more SWFs have been created than ever before and more than the previous 50 years put together. According to the SWF Institute 26 SWFs were created before 2000, investing state-owned profits proceeding from fiscal surpluses and natural resources such as oil, gas or copper. The commodity boom of the 2000s, the rise of emerging countries and especially the current account surpluses of fast growing Asian countries boosted the creation of SWFs. Among others, China, Russia and Dubai created their own SWFs. The amount of capital accumulated by most SWFs has recently dramatically increased due to the increasing price of commodities such as oil. ${ }^{1}$

This phenomenon of SWFs emergence has continued to grow despite the economic downturn, the market volatility, the sovereign debt crisis and the decline of commodity and oil prices in recent years. 43 SWFs were created between 2005 and 2014 (25 since January 2008). The number of existing and potential funds exceeds one hundred, but there are currently 78 SWFs in activity, with assets amounting to 7.4 trillion dollars (SWF Institute). This development concerns not only developed countries but also all emerging countries, not just Asia and the Middle East but Latin America and Africa too. This is the case, for example, of Angola, Nigeria and Panama that established a SWF in 2012. Very recently, Israel has established a new SWF, "Israeli Citizens' Fund" whose purpose is to safeguard the windfall revenues made from natural gas. ${ }^{2}$ Some other countries that are planning to establish new SWFs are Bolivia, Canada, Japan, India, Taiwan and Thailand.

There is no consensus, in either the academic or practitioner literature, on what exactly is a SWF. Most definitions of SWFs suggest that these are "state owned funds that obtain their funding from their foreign-currency reserves or commodity export revenues; in certain instances, government budget surpluses and pension surpluses can be transferred to SWFs" (IMF (2008) [22], Butt et al. (2008) [8]). Confronted to this accumulation of foreign-currency reserves, policymakers can lay down a number of development objectives which they deem appropriate. Such pursued objectives are diversified, including the stabilisation of fiscal revenues, the financing of pensions, savings for future generations, the optimisation of the returns or the diversification of the economy. In order to meet their policy objectives, one issue that policymakers will face is to determine whether or not they should set up a SWF. Once they have decided to set up a fund, policymakers will have to define operational objectives as well as a strategic asset allocation consistent with their policy objectives. When

1. This is clearly the case of Gulf SWFs that own about $42 \%$ of the total SWFs assets.

2. The activities of this fund are expected to start in 2017. 
the size of foreign-currency reserves is considerable, policymakers can follow several broad policy objectives at the same time and decide to establish not one but two or more SWFs depending on the objectives assigned to each.

Given the increasing number of SWF creations in recent years and their increasing importance in advanced and emerging countries, the question of why a country decides to set up a SWF has become of major importance. In line with the huge literature trying to answer the question of the optimal level of exchange reserves, the decision of setting up a SWF is closely linked to the excess of exchange reserves. It is also mostly linked to the origins of these ample reserves and to the longevity of these sources. This was clearly the case after commodity price booms during the seventies and in the last few years, after a new resource was discovered or when administration of an existing resource was being restructured. In that case, the level of foreign reserves brutally increases in a long-lasting way and the country may consider what is the adequate level of revenues. It can also determine what part of these revenues can be considered in excess and can be set aside. The motivation for launching a SWF is therefore to allow "excess" foreign exchange reserves to be channeled away from low-yielding sovereign bonds to higher-return equity and corporate debts investments. Examples of countries that have set up a SWF after a new natural resource was found are Brazil (after large oil deposits were discovered), Israel (after two big gas fields were found) or Mongolia (after mining concessions were granted). This was also the case of other SWFs like the funds of Papua New Guinea and Ghana. ${ }^{3}$

Another reason that can explain the decision of setting up a SWF is the commodity price volatility. A boom of commodity prices, such as that in the 1970 s and in the last years for oil, tends to swell the sovereign asset holdings of commodity-exporting countries whereas the drop of oil price has the reverse effect. Countries specialized in natural resources are therefore extremely dependent on the price of these natural resources and on their volatility. To deal with these concerns, policymakers can decide to save a share of the gains from the boom of commodity prices in a sovereign wealth fund aimed at stabilizing the fiscal impact of fluctuating commodity prices and smoothing boom or bust cycles. The recent decrease of energy prices and more particularly oil prices does not reduce at all the strategic importance of commodity-based funds, because most of them were established to increase the economic resilience of petroleum exporting countries to the depletion of their reserves and the volatility of resources prices.

When a country is dependent on its natural resources, a boom of commodity prices or the discovery of a new natural resource can lead to inflationary pressures and an appreciation of the real exchange rate, which then damages the non-resource tradable sector. This phenomenon is known in the academic literature as "Dutch Disease". Commodities-exporting countries which suffer from Dutch Disease are for example Canada, Australia and Norway (Corden and Neary (1982) [13], Beine et al (2014) [5]). One of the possible policies to prevent an occurence of the Dutch Disease or to mitigate its effects associated with booms in natural

3. Papua New Guinea Sovereign Wealth Fund as well as the Petroleum Holding Fund and the Ghana Petroleum Funds were established in 2011. 
resources sectors could be the creation of a SWF which may allow that the proceeds of the fiscal surplus go out of the domestic economy.

The fact that many funds have continued to be set up in recent years despite the economic downturn, the market volatility, the sovereign debt crisis and the decline in commodity and oil prices shows that criteria other than economic can also explain the decision. In particular, some countries like Angola and Nigeria, that have set up a fund recently, have low governance and/or are non-democratic countries. Natural resources rents have often been related to waste and corruption and consequently to poor long run economic performance (Sala-i-Martin and Subramanian (2003) [34]). The decision of setting up a SWF for a country can therefore have a political dimension. Even if the declared objective of SWFs created by autocratic countries is to ensure that the proceeds from natural resources rents will be channeled through a transparent, accountable and professionally managed fund, these SWFs are a mean for these countries to embezzle natural resource revenues in order to invest abroad. An important concern with SWFs created by developing countries is the unethical nature of these funds coupled with the autocratic and authoritarian nature of the countries where these funds are establishing. Setting up a SWF for these countries can be seen as a mean to expand their wealth and their financial power through long-term investment strategies involving assets in Western countries as it is the case for Gulf SWFs.

Although the literature analyzing SWFs investment strategies and how SWFs impact target-firm economies has been important over the past decade ${ }^{4}$, there are very few studies questioning the rationale for SWF creation, probably due to data constraints but also due to a "western bias" in most of the related research (Aizenman and Glick (2009) [? ], Carpantier and Vermeulen (2014) [9], Das et al. (2009) [14], Megginson and Fotak (2015) [29]). The paper aims to fill the gap by assessing the determinants of the SWF's creation. More precisely, we would like to test whether there are some countries for which the creation of a SWF is more appropriate. Using a large-scale database, we analyze the economic, political and institutional factors of countries which decided to establish a SWF. In particular, we test if the emergence of a SWF can be explained by the following factors : 1) the excess foreign exchange reserves due to natural resources rents or persistent current account surpluses; 2) the volatility of commodity prices; 3) a way to mitigate the "Dutch Disease" effect; 4) the governance of the country. We test these hypotheses on a sample of 37 countries that established a SWF over the period 2000-2014 and compare them to a large panel of countries that have also natural resources rents but that did not set up a SWF. In order to allow the temporal dimension as well as the unobserved heterogeneity between SWFs, a Logit panel model with random effects is estimated. The panel dimension in the model allows to take into account the temporal dimension which is essential for explaining the number of funds created by year as well as the unobserved heterogeneity between the different SWFs. In the same way, the inclusion of random effects allows to control for omitted variables.

The remainder of the paper is presented as follows : in Section 2, we present the theoretical framework and empirical hypotheses. Section 3 provides some details regarding the

4. For an exhaustive literature on SWFs see the excellent survey of Megginson and Fotak (2015) [29]. 
data, Section 4 presents the model and Section 5 presents our empirical findings. Finally, Section 6 concludes.

\section{Theoretical framework and empirical hypotheses}

How can we explain the decision of setting up a Sovereign Wealth Fund for a country? Should countries with large, and maybe temporary excess cash flows allocate a part of these flows to a SWF? Is this decision based on economic, financial and/or political factors? Although the literature on the determinants of SWFs' investments has been important over the past decade ${ }^{5}$, very few studies question why a government decides to set up a SWF and uses it to invest abroad rather than using the revenues to invest in its own economy.

Among these few studies, Aizenman and Glick (2009) [2] analyze the determinants of the existence of SWFs in 2007 and 2008 and find that the main determinants are full export, foreign exchange reserves and current account surpluses. Griffith-Jones and Ocampo (2012) [19] analyze the rationale for the existence of SWFs from a developing country perspective. They find that the decision to create a fund depends on the origins of excess foreign exchange reserves, on the longevity of these sources and on the other assets and liabilities of the country. In the same way, Carpantier and Vermeulen (2014) [9] test if the emergence of a SWF is determined by the existence of natural resource profits, the government structure and the ability to invest in the domestic economy over the period 1998-2008. They conclude that SWFs tend to be established in countries with an autocratic regime and that have difficulties finding suitable opportunities for domestic investments.

The paper aims to fill the gap by assessing the determinants of the creation of a SWF. For that purpose, we analyze the economic, political and institutional characteristics of countries that decided to set up a SWF. In particular, we test if the emergence of these new recent funds can be explained by the following factors : 1) the accumulation of exchange reserves due to natural resources rents or persistent current account surpluses; 2) the volatility of commodity prices; 3) a solution to mitigate the "Dutch Disease" effect as well as "the natural resource curse" and 4) the governance of the country.

H1 - The accumulation of exchange reserves due to natural resources rents or persistent current account surpluses increases the probability of setting up a SWF.

As mentioned by Das et al. (2009) [14], there is no theoretical model for deciding the level of exchange reserves that is sufficient for a country and above which the government can consider the possibility of setting up a SWF. In perspectives of asset-liability and public asset management, the government should optimize asset allocation choices by considering its balance sheet in its entirety. For that, it should identify all financial assets and liabilities by taking into account commodity values and future tax revenue. In a crisis prevention perspective, the most relevant indicator is the ratio of international reserves to short-term

5. See the detailed survey of Megginson and Fotak (2015) [29] on this issue. 
external debt. A value of one for this ratio means that a country with a balanced current account will have sufficient reserves to cover its obligations for one year. The level of necessary reserves should be higher if the external current account of the country is in deficit, the exchange rate is overvalued or the banking system is weak. This level of reserves can be more limited in the case of a flexible exchange rate regime or if the government can quickly borrow large amounts from non-residents. ${ }^{6}$

When the adequate threshold of exchange reserves or fiscal revenues is reached, it is not necessarily appropriate to set up a SWF. In a first step, the Central Bank can decide to manage exchange reserves in a long-run perspective. Likewise, a cyclical budgetary surplus can cover a structural potential deficit or reduce the public debt. It is only when the accumulation of the exchange reserves or fiscal revenues is considered in a permanent way and when the financial conditions are favorable that it may be appropriate to set up such a fund. This is particularly true when the accumulation of foreign reserves is accompanied by considerable social costs especially in developing countries as shown by Rodrick (2006) [31] or Fukuda and Kon (2010) [17]. ${ }^{7}$

In line with the huge literature trying to answer the question of the optimal level of exchange reserves, the decision of setting up a SWF is therefore closely linked to the excess of exchange reserves. Is is also mostly linked to the origins of these reserves and the longevity of these sources. This is clearly the case when a new natural resource is discovered or when the administration of an existing resource is restructured. In that case, the level of foreign reserves brutally increases in a long-lasting way and the country may consider what is the adequate level of revenues. It can also determine what part of these revenues can be considered in excess and can be set aside. This is also the case for non-commodity-exporting countries which have large and persistent current account surpluses (see Aizenman (2007) [1]). When sovereign assets reach a sufficient level to ensure that the liquidity needs of the country are met, policymakers become more risk-tolerant and are ready to allocate excess reserves to one or several different accounts depending on the assigned objectives. The motivation for launching a SWF is therefore to allow "excess" foreign exchange reserves to be channeled away from low-yielding sovereign bonds to higher-return equity and corporate debts investments.

Related to this theory, we would like to test whether ample exchange reserves due to either the discovery of new natural resources rents or to large and persistent current account surpluses increase the probability of setting up a SWF. Even if 'excess' foreign exchange reserves seem to be an obvious determinant of the decision of setting up a fund, assessing this hypothesis will allow to verify whether countries with excess reserves systematically set up a SWF.

6. Jeanne and Ranciere (2006) [25] and Jeanne (2007) [24] have developed theoretical models to answer the question of the optimal level of reserves in a cost-benefit framework.

7. Rodrick (2006) [31] finds that social costs of the accumulation in foreign reserves for a developing country amount to around 1 percentage point of GDP annually. 
H2 - SWFs are set up to insulate the budget and economy from the volatility of natural resource prices and external shocks.

Another reason that can explain the decision of setting up a SWF is the commodity price volatility. A boom of commodity prices, such as that in the 1970s and in the last years for oil, tends to swell the sovereign asset holdings of commodity-exporting countries whereas the drop of oil price has the reverse effect. Countries specialized in natural resources are therefore extremely dependent on the price of these natural resources and on their volatility. Commodity prices, and more particularly oil and natural gas prices, are volatile because of low short-run elasticities : in case of oil price increase for example, the demand does not fall much in the short run nor does supply rise. As a result, in case of external shock, the price has to rise in order to clear the market (Frankel (2012) [15]). In particular, when oil-exporting countries know windfall gains associated with a sharp rise in the oil price, it induces for these countries an increase of government spending and this spending will fall sharply when oil prices will collapse. A great number of existing studies find that the volatility of natural resources prices is bad for the economic growth of the country (see Blattman et al. (2007) [7], Hausmann and Rigobon (2003) [20] or Van der Ploeg and Poelhekke (2009) [38] among others).

To deal with these concerns, policymakers can decide to save a share of the gains from the boom of commodity prices in a sovereign wealth fund aimed at stabilizing the fiscal impact of fluctuating commodity prices and smoothing boom or bust cycles. This counter-cyclical role in relation to commodity world prices is particularly important when the economy of the country is dependent on commodity exportations.

H3 - SWFs are set up to mitigate the "Dutch Disease" effect as well as "the natural resource curse".

When an economy is dependent on its natural resources, a boom of commodity prices or the discovery of a new natural resource can lead to inflationary pressures and an appreciation of the real exchange rate, which is detrimental to economic growth. This phenomenon is known for the economists as "Dutch Disease" in reference to the experience of the Netherlands after the natural gas discoveries in the 1960s. ${ }^{8}$ As a matter of fact, a strong, but perhaps temporary, upward swing in the world price of the export commodity results in a sharp increase of budgetary revenues of the exporting country. It induces inflationary pressures when these revenues are spent (especially when the government increases spending in response to the increase of tax receipts and royalties). Such a situation also significantly increases foreign currencies entries and in particular US dollars. The conversion in local currency means an increased demand for this latter and therefore a large real appreciation of the currency (taking the form of a currency appreciation if the country has a floating exchange rate or the form of money inflows and inflation if the country has a fixed exchange rate), which leads to a loss of price competitiveness of traded goods. These effects cause an increase in the price of non-traded goods (goods and services that are not internationally

8. See the reference paper of Corden and Neary (1982) [13] on the modeling of the Dutch Disease issue. 
traded) relative to traded goods (manufactured and other internationally traded goods other than the export commodity). The production factors like capital and labor turn to the export commodity and non-traded goods sector at the expense of the tradable sector. Therefore the exploitation of natural resources can lead to a low diversified growth at the sectoral level, without other export than commodities. As explained by Frankel (2012) [15] in his survey, we speak about a disease because these effects are sustainable and the process is not reversed or is painfully reversed when the world price of export commodity goes down.

One of the possible policies to deal with the Dutch Disease problem is the creation of a SWF. As explained by Corden (2012) [12], a fiscal surplus generated by tax and expenditure would reduce demand for domestic goods and services and therefore would be deflationary. The domestic interest rate would decrease and then would lead to a depreciation of the exchange rate and a mitigation of the Dutch Disease effect. It is desirable that the proceeds of the fiscal surplus do not finance investment at home because this would cause again an increase of aggregate demand for domestic goods and services and hence that would amount to negating the initial deflationary effects of the fiscal surplus. The creation of a SWF allows that the proceeds go out of the domestic economy : " the proceeds might go into a Sovereign Wealth Fund that invests its funds wholly abroad" (Corden (2012), [12], p.14). Saving the proceeds abroad in a fund can therefore assist in mitigating Dutch Disease and related macroeconomic consequences. In the same spirit, Frankel (2012) [15] suggests that the proceeds of fiscal surplus should be used to set up a transparent SWF which would assure that future generations benefit from the natural resource windfall. Furthermore, the latter could be invested by the fund in assets that earn higher return than the return on US treasury bills. This is clearly the aim of saving funds which are intended to fight against pernicious effects of natural resource over-exploitation, like the Dutch Disease.

We would like to test whether the probability of setting up a SWF increases for resourcerich countries knowing Dutch Disease. More precisely, as the first effect of the Dutch disease is a commodity-driven appreciation of the currency leading to a decline in the competitiveness of the domestic manufacturing sector, we try to test whether the probability of setting up a fund increases for resource-rich countries knowing an appreciation of the real exchange rate.

H4 - Countries with low democratic political institutions should be more likely to have SWFs.

In line with the literature on Dutch Disease, many studies refer to the "natural resource curse" for explaining the poor performance of resource-rich countries (see among others Sachs and Warner (1995, 2001) [32], [33], Kaldor et al. (2007) [26], Sala-i-Martin and Subramanian (2003) [34] or Smith (2004) [35]). The natural resource curse hypothesis provides that it is not the economy dependence on natural resource revenues but the abundance of the latter that would be responsible for the low economic growth. In case of a boom of commodity prices, considerable revenues from the exploitation of natural resources lead to a specialization of the exports in commodities according to the Dutch Disease theory. But when the world prices fall, natural resources rents still penalize the long-run economic growth. This abundance encourages the authorities to think that they will have higher proceeds once 
world prices will rise again. These expectations cause an increase in the public debt which can become excessive (Gelb, (1988) [18]). The abundance of budgetary revenues induces an increase of the state's current expenditures (wages and social transfers) and unprofitable or too ambitious public investments. Related to this, many studies find that concentration of natural resources is strongly associated with weak public institutions and therefore with slower growth (Isham et al. (2003) [23], Sala-i-Martin and Subramanian (2003) [34]). For example, Sala-i-Martin and Subramanian (2003) [34] show from the Nigerian experience that waste and corruption from oil rather than Dutch Disease have been responsible for the poor long-run growth of the country. In the same way, natural scarcity and abundance of these resources for one minority of countries have been cited as a cause of civil war.

The decision of setting up a SWF for a country can therefore have a political dimension. We expect that countries with low democratic political institutions should be more likely to have SWFs. According to the natural resource curse theory, countries with weak institutions generally have natural resource wealth that leads to resource dependency and rentierism. Even if the declared objective of these SWFs is to ensure that the proceeds from natural resources rents will be channeled through a transparent, accountable and professionally managed fund, they are a mean for autocratic countries to embezzle natural resources revenues in order to invest abroad. This is clearly the case of reserve investment funds that aim to maximise the returns of funded assets subject to a low risk tolerance (Das et al. (2009) [14]). The creation of a SWF for countries that are both politically and financially less open than developed countries can be viewed as a means to leverage their political influence abroad. These funds are generally managed in a non-transparent way, increasing the distrust of developed countries: "When an increasing number of governments in non-democratic countries decided to create and expand SWFs, the critics particularly question the validity of the existing rules regulating the free market system" (Chong and Bahgat, p.8 (2016) [11]).

We would like to test the four hypotheses described above, which try to explain whether the decision to create a SWF is based on economic, institutional and political factors, although we recognize that variables serving to capture the factors may be working through multiple mechanisms.

\section{Data and descriptive analysis}

\subsection{Creation of the SWFs sample}

There is little consensus on a definition of what a SWF actually is, which explains the great variety of definitions given by authors. The lack of consensus on what really constitutes a SWF is due to the fact that these funds form a heterogeneous group of investors grouped into the SWF category. There is however differences between funds with respect to their sources and size of assets, organizational structure, governance, risk factor and their objectives. An unanimously accepted definition is the one given by the International Monetary Fund : "Sovereign wealth funds are government-owned investment funds set up for a variety a macroeconomic purposes. They are commonly funded by the transfer of foreign exchange assets that are invested in the long term, overseas." (Al Hassan et al. (2013) [3]). Therefore, 
the IMF defines SWFs as government-owned investment funds based on their objectives : i) stabilization funds designed to mitigate volatile commodity prices; ii) saving/pension funds aimed to share wealth across future generations and financing pensions; iii) reserve investment corporations intended to reduce the opportunity cost of holding excess foreign reserves and to search for investment policies with higher returns and iv) development/domestic economic support funds aimed to support domestic economy.

Considering this definition, we conducted a search of all existing SWFs by using different sources in order to have the most complete list. We start with a preliminary sample of SWFs given on the SWF Institute website ${ }^{9}$ by combining the names of funds published by JP Morgan (Fernandez and Eschweiler, 2008 [16]), Catalano (2009) [10], Lyons (2007) [28], ESADEgeo studies on SWFs published every year (see for example Santiso, 2012 [36]) and the websites of the SWFs. When different names for the same SWF are found, we employ the fund's websites to eliminate duplicates.

This search yields a sample of 92 existing SWFs all over the world and 53 funds setting up over the period 2000-2014 from 37 countries. We capture about 58\% of existing funds over the considered period in our dataset as the majority of SWFs have been created after 2000. ${ }^{10}$ The Appendix gives the complete list of SWFs created over the period 2000-2014 and some information on these funds (country of origin, the estimated fund size, the source of funding, the year in which the fund was established and the declared objective of the fund).

In order to avoid selection bias, we consider in our sample not only the 37 countries that established a SWF during the considered period but also 53 other countries randomly selected (developed and developing countries, with and without natural resources rents) that did not create a SWF during the period or that already created one before 2000. Some countries have been excluded from our database because of unavailability of data. ${ }^{11}$ As we have a binary decision, i.e setting-up a SWF or not - a logistic regression can be approached. As we look at the country level with a panel dimension, our dependent variable is equal to 1 over the year of the establishment of one or several SWFs for the country. ${ }^{12}$ The panel dimension in the model allows to take into account the fact that a country can have set up several SWFs over the considered period. It is the case for 10 countries which have created more than one SWF over the period.

Table 1 reports the annual distribution of SWFs created over the period 2000-2014 all

9. http ://www.swfinstitute.org/.

10. As our sample begins in 2000, it does not include some funds like the Norwegian SWF (created in 1990, US $\$ 873$ billion in 2015, third largest fund), the Abu Dhabi Investment Authority (1976, US $\$ 773$ billion in 2015, fifth biggest fund) or the Kuwait Investment Authority (1953, US\$592 billion in 2015, sixth biggest fund). Source : SWF Institute. However, as our focus is on the emergence of new funds, the size of the funds does not matter in our analysis.

11. Among these countries, six established a SWF over the period 2000-2014. These countries are Equatorial Guinea, Mauritania, Sao Tome and Principe, Timor-Leste, Turkmenistan and Chad

12. Three countries (China, Russia and the United Arab Emirates) decided to set up two SWFs in the same year. 
Table 1: Annual Distribution of SWFs establishment

This table presents the number of SWFs established between 2000 and 2014. Column 4, (resp. 6) gives the number of commodity-based SWFs (resp. non-commodity-based SWFs). Column 3 gives the proportion of SWFs created in the year $t$ among all the SWFs created over the period 2000-2014. Column 5 (resp. 7) gives the proportion of commodity-based SWFs (resp. non-commodity-based SWFs) created the year $t$ among all the commodity-based SWFs (resp. non-commodity-based SWFs) created over the period 2000-2014.

\begin{tabular}{ccccccc}
\hline & $\begin{array}{c}\text { Number } \\
\text { of SWFs }\end{array}$ & $\begin{array}{c}\text { Proportion } \\
\text { (All SWFs) }\end{array}$ & $\begin{array}{c}\text { Number of } \\
\text { Commodity } \\
\text { SWFs }\end{array}$ & $\begin{array}{c}\text { Prop. Com. } \\
\text { SWFs }\end{array}$ & $\begin{array}{c}\text { Number of } \\
\text { Non-Commodity } \\
\text { SWFs }\end{array}$ & $\begin{array}{c}\text { Prop. Non-com. } \\
\text { SWFs }\end{array}$ \\
\hline \hline 2000 & 5 & $9.4 \%$ & 4 & $12.5 \%$ & 4 & $14.3 \%$ \\
2001 & 1 & $1.9 \%$ & 0 & $0 \%$ & 0 & $0 \%$ \\
2002 & 2 & $3.8 \%$ & 2 & $6.3 \%$ & 2 & $7.1 \%$ \\
2003 & 2 & $3.8 \%$ & 1 & $3.1 \%$ & 1 & $3.6 \%$ \\
2004 & 0 & $0 \%$ & 0 & $0 \%$ & 0 & $0 \%$ \\
2005 & 5 & $9.4 \%$ & 3 & $9.1 \%$ & 3 & $10.7 \%$ \\
2006 & 7 & $13.2 \%$ & 3 & $9.4 \%$ & 2 & $7.1 \%$ \\
2007 & 6 & $11.3 \%$ & 4 & $12.5 \%$ & 3 & $10.7 \%$ \\
2008 & 6 & $11.3 \%$ & 3 & $9.4 \%$ & 3 & $10.7 \%$ \\
2009 & 1 & $1.9 \%$ & 0 & $0 \%$ & 0 & $0 \%$ \\
2010 & 0 & $0 \%$ & 0 & $0 \%$ & 0 & $0 \%$ \\
2011 & 8 & $15.1 \%$ & 6 & $18.8 \%$ & 5 & $17.9 \%$ \\
2012 & 8 & $15.1 \%$ & 4 & $12.5 \%$ & 3 & $10.7 \%$ \\
2013 & 0 & $0 \%$ & 0 & $0 \%$ & 0 & $0 \%$ \\
2014 & 2 & $3.8 \%$ & 2 & $6.3 \%$ & 2 & $100 \%$ \\
\hline Total & 53 & $100 \%$ & 32 & $100 \%$ & 21 & \\
\hline \hline
\end{tabular}

over the world by distinguishing them between commodity versus non-commodity funds. Even if the creation of this new state-owned investment vehicle is not a new phenomenon, there has been a significant increase of the number of SWFs established since 2000. Table 1 shows that 53 SWFs have been launched since 2000, with more than $30 \%$ of funds in the last five years. In contrast with other investors (pension funds, private equity,..) who withdrew from the market during the financial crisis, SWFs continued to grow in number, with $22 \%$ of funds created in 2007-2008. The financial crisis has however stopped the evolution in the two years 2009-2010 but the fat years in terms of SWFs number growth are 2011-2012 with $30 \%$ of new funds.

According to their source of funding, SWFs can be grouped as commodity-based SWFs and non-commodity SWFs. Commodity-based SWFs are funded mainly from oil exports, gas or other minerals, while non-commodity SWFs are funded by the transfer of assets from both government budget surpluses and excess foreign reserves. Considering the fund's source of proceeds (commodity or non-commodity funds), Table 1 shows that $60 \%$ of SWFs created over the period 2000-2014 are commodity-based funds (oil, gas and other commodities). A lesser but significant proportion (40\%) of SWFs are funded by non-commodity sources, including the biggest fund of China (China Investment Corporation established in 2007), the South Korean SWF (Korea Investment Corporation established in 2005).

Table 2 gives the geographic distribution of SWFs created over the period 2000-2014 by 
distinguishing commodity and non-commodity funds. SWFs are, for the most part, from emerging countries as only $25 \%$ of them are from OECD countries (with about $11 \%$ in Europe and in North America). The majority are from Middle East (21\%), Africa (17\%) and Asia (13\%). Considering the fund's source of proceeds (commodity or non-commodity-based funds), commodity-based funds are mainly located in Middle East (28\%), Africa (22\%) and OECD countries (22\%), whereas non-commodity-based funds are mostly in Asia (29\%) and OECD countries (29\%). Non-commodity-based funds are much larger than commodity-based funds as their assets under management are in mean USD 74.29 billion whereas commoditybased funds manage in mean USD 33.65 billion.

Table 2: Geographic Distribution of SWFs Foreign Investments

This table presents the number of commodity and non commodity SWFs created by region over the period 2000-2014. The second line of each region gives the proportion of commodity (resp. non-commodity) SWFs in region $\mathrm{K}$ among all commodity (resp. non-commodity) SWFs around the world.

\begin{tabular}{lccc}
\hline Region & Commodity funds & Non-Commodity Funds & Total Number of SWFs \\
\hline \hline \multirow{2}{*}{ Africa } & 7 & 2 & 9 \\
& $22 \%$ & $10 \%$ & $17 \%$ \\
\hline \multirow{2}{*}{ East and Southeast Asia } & 1 & 6 & 7 \\
& $3 \%$ & $29 \%$ & $13 \%$ \\
\hline \multirow{2}{*}{ Middle East } & 9 & 2 & 11 \\
& $28 \%$ & $10 \%$ & $21 \%$ \\
\hline \multirow{2}{*}{ Oceanic Bassin } & 1 & 0 & 1 \\
& $3 \%$ & $0 \%$ & $2 \%$ \\
\hline \multirow{2}{*}{ OECD Countries } & 7 & 6 & 13 \\
& $22 \%$ & $29 \%$ & $25 \%$ \\
\multirow{2}{*}{ Russia and Central Asia } & 4 & 2 & $11 \%$ \\
\hline \multirow{2}{*}{ South America } & $13 \%$ & 3 & 6 \\
& 3 & $14 \%$ & $11 \%$ \\
\hline \hline \multirow{2}{*}{ All Regions } & $9 \%$ & 21 & 53 \\
& 32 & $100 \%$ & $100 \%$ \\
\hline \hline Mean AUM (bln $\$)$ & 33.65 & 74.29 & 49.75 \\
\hline \hline
\end{tabular}

Table 3 reports the distribution of SWFs created over the period 2000-2014 by distinguishing them according to their objectives defined above. The objectives of the funds have been deduced from the websites of SWFs. In practice, SWFs may have several different objectives depending on the source of funding. Most of SWFs (36\%) are established with the primary aim to support the domestic economy. 34\% of SWFs created since 2000 have a macro-stabilization objective. This is particularly the case for countries that are highly dependent on commodity exports and therefore exposed to swings in global prices (47\% of macro-stabilisation funds are commodity-based funds). $25 \%$ of SWFs are established in order to save for future generations of finance pensions. Reserve investment funds are less represented (21\%) but they are those which manage the largest assets (USD 119.58 billion). This results are in line with those of Kimmit (2008) [27] who notes that commodity-based funds are prone to multiple and changing objectives mostly based on fiscal revenue stabilization 
whereas non-commodity-based funds are more commonly used to make investments when a country has accumulated excess foreign exchange reserves.

Table 3: SWFs by objectives

This table presents the number of SWFs with objective $j$ created over the period 2000-2014. The second line of each region gives the proportion of SWFs with objective $j$ among all SWFs. Column (3) and (4) give respectively the number of Commodity-based SWFs and Non-Commodity-based SWFs with objective $j$.

\begin{tabular}{lcccc}
\hline Objective & Total number of funds & Commodity funds & Non-commodity funds & $\begin{array}{c}\text { Mean AUM } \\
\text { (bln \$) }\end{array}$ \\
\hline \hline \multirow{2}{*}{ All objectives } & 53 & 32 & 21 & 49.75 \\
\hline \multirow{2}{*}{ Macrostabilisation } & $100 \%$ & $100 \%$ & $100 \%$ & 25.64 \\
\hline \multirow{2}{*}{ Saving/Pension } & 18 & 15 & 3 & 32.64 \\
\hline \multirow{2}{*}{ Reserve Investment } & $13 \%$ & $47 \%$ & 5 & \multirow{2}{*}{119.58} \\
& $25 \%$ & $25 \%$ & $24 \%$ & 24.57 \\
\hline Domestic Economic & 11 & 7 & $29 \%$ & 11 \\
Support & 19 & $22 \%$ & $52 \%$ & 2 \\
\hline \hline
\end{tabular}

\subsection{Other data}

We employ a number of variables that should potentially explain the decision of setting up a SWF for one country. These variables relate to macroeconomic and institutional country factors and aim to test the theoretical hypotheses explained above.

Among the selected macroeconomic variables, the wealth effect of a country is captured by the annual variation of the GDP (denoted $\Delta \log G D P$ ). For the econometric analysis, the GDP series are expressed in logarithmic form to preempt the usual problem of heteroskedasticity when using the original index numbers.

The main potential determinants of the fund's creation are related to revenue inflows, i.e. excess foreign exchange reserves due to natural resource rents for resource-rich countries and current account surplus for non-commodity countries. We consider as proxy of excess foreign exchange reserves - reserves in excess of traditional balance of payments needs - a dummy variable equal to 1 if the ratio of international reserves to short-term external debt is above $100 \%$ and 0 otherwise (EXCESS RESERVES). ${ }^{13}$ As evoked in Hypothesis 1, the underlying idea is that the creation of a SWF for a country may only be considered when external debt has been considerably reduced and/or when there is a source of increasing reserves (for example windfalls due to the discovery of a new natural ressource). The natural resources

13. Excess foreign exchange reserves are generally proxied in the literature by two traditional rule-of-thumb measures : i) the difference between actual foreign exchange reserves and the value of three months of imports; ii) the ratio or the difference between actual foreign exchange reserves and total short-term external debt (see for example Beck and Fidora (2008) [4]). 
rents $(R E N T)$ are measured by the sum of total natural resources rents (oil, gas, mineral) in percentage of GDP. We expect both variables to be positive as the more a country accumulates wealth and natural resource rents, the more likely the country is to create a SWF. Another important determinant of the fund's creation for non-commodity countries (like for example for Asian countries) is the current account surplus. Unfortunately, this variable is unavailable for many countries in our panel dataset but can be proxied by excess foreign exchange reserves.

As the main objective of macroeconomic stabilization funds is to smooth short and medium-term commodity price fluctuations and as more than $50 \%$ of countries which created a SWF between 2000 and 2014 are oil-exporting countries, we consider that the variation of oil prices (OILPRICE) is an important determinant of the fund's creation as explained in Hypothesis 2.

In order to test whether SWFs may be created in order to mitigate the "Dutch Disease" effect (Hypothesis 3), we employ the variation of the real effective exchange rate $(\triangle R E E R)$. As the first "Dutch disease" effect for a resource-rich country is a commodity-driven appreciation of the currency in the short run (Corden and Neary (1982) [13]), we test whether the probability of setting up a fund increases for resource-rich countries knowing an appreciation of the real exchange rate in the short run. ${ }^{14}$ We select effective rather than bilateral real exchange rates as the former give a trade-weighted measure of the international competitiveness of a country against all its trade partners. This selection avoids potential biases associated with the arbitrary choice of a base country for a bilateral real exchange rate analysis.

Theoretical considerations developed in Hypothesis 4 suggest that SWFs are more likely to get created in countries with low governance in terms of government effectiveness, regulatory quality and corruption control. Institutional variables measuring the level of political risk of the country are a corruption dummy variable (CORRUPTION) that equals 1 if the country is corrupted and 0 otherwise. The level of authority of the regime (democracy versus autocracy) is a dummy variable based on the Polity IV index (POLITY) that equals 1 if the country is autocratic and 0 otherwise. We expect these variables to be positively related to the decision of setting up a SWF. As underlined in Hypothesis 4, concentration of natural resources is strongly associated with weak public institutions. Therefore, we include in our analysis two interaction variables : one between RENT and POLITY $($ RENT $\times$ POLITY $)$ and the other between RENT and CORRUPTION (RENT $\times$ CORRUPTION). We expect both variables to be positively related to the decision of setting up a SWF. Appendix 2 reports the source and the definition of each variable employed in our study.

Table 4 provides bilateral t-tests of the mean differences that exist between countries with

14. The literature on "Dutch Disease" (see among others Van der Ploeg, 2011 [37] ; Frankel, 2012 [15]) shows that the heavy reliance on natural resources tends to hinder the accumulation of human and physical capital in the country. This is detrimental for the evolution of the productive capacity of the country and its competitiveness, which is reflected by a long-run depreciation of the real effective exchange rate. 
a SWF and those without in our dataset. Over the period 2000-2014, countries that have established a SWF reported on average higher GDP, higher natural resources rents and higher foreign exchange reserves than countries without SWF, with statistically negative mean difference. These results confirm that on average countries with higher revenues are more likely to establish a SWF (Hypothesis 1). Concerning institutional variables, our sample dataset shows that countries with a SWF exhibited on average a higher level of corruption $(77 \%$ of corrupted countries against $2 \%$ for countries without a SWF), with statistically positive mean difference. This suggests that countries with a high corruption level are more likely to establish a SWF than democratic ones, which seems to be consistent with our Hypothesis 4. As described in Table 5, the correlation between some variables is quite high, stressing that some variables can not be estimated in the same model.

Table 4: Bilateral tests of mean differences across SWF countries and No-SWF countries

This table presents the p-value of two-group mean-comparison tests performed across countries that have created at least one SWF over the period (SWF countries) and countries that did not create a SWF (No-SWF countries). $H_{0}: M_{\text {ean }}$ Non-SWFCountries $-M_{\text {ean }}$ SWCountries $=0$. There are three alternative hypothesis : t-test 1 - the difference is significantly different from 0 ; t-test 2 - the difference is significantly inferior to 0 ; t-test 3 - the difference is significantly superior to 0 .

\begin{tabular}{lrrrrrrr}
\hline Variable & $\begin{array}{r}\text { SWF } \\
\text { countries }\end{array}$ & $\begin{array}{r}\text { No-SWF } \\
\text { countries }\end{array}$ & $\begin{array}{r}\text { p-value } \\
\text { t-test 1 }\end{array}$ & & $\begin{array}{r}\text { p-value } \\
\text { t-test 2 }\end{array}$ & & $\begin{array}{r}\text { p-value } \\
\text { t-test3 }\end{array}$ \\
\hline GDP & $8.07 \mathrm{e}+11$ & $3.33 \mathrm{e}+11$ & 0.000 & $* * *$ & 0.000 & $* * *$ & 1.000 \\
RENT & 21.418 & 10.504 & 0.000 & $* * *$ & 0.000 & $* * *$ & 1.000 \\
RESERVES & 0.212 & 0.180 & 0.013 & $* *$ & 0.006 & $* * *$ & 0.994 \\
REER & 104.092 & 102.391 & 0.181 & & 0.091 & $*$ & 0.910 \\
CORRUPTION & 0.768 & 0.018 & 0.000 & $* * *$ & 0.000 & $* * *$ & 1.000 \\
POLITY & 0.324 & 0.302 & 0.378 & & 0.189 & & 0.812 \\
\hline \hline
\end{tabular}

Table 5: Correlation matrix

\begin{tabular}{|c|c|c|c|c|c|c|c|c|c|}
\hline Variable & $\Delta \log \mathrm{GDP}$ & RENT & $\begin{array}{c}\triangle \mathrm{OIL} \\
\mathrm{PRICE}\end{array}$ & $\begin{array}{c}\text { EXCESS } \\
\text { RESERVES }\end{array}$ & $\triangle$ REER & $\begin{array}{l}\text { CORRU- } \\
\text { PTION }\end{array}$ & POLITY & $\begin{array}{c}\text { RENT } \\
\text { xCORR }\end{array}$ & $\begin{array}{c}\text { RENT } \\
\text { xPOLITY }\end{array}$ \\
\hline$\Delta \log \mathrm{GDP}$ & 1.000 & & & & & & & & \\
\hline RENT & 0.243 & 1.000 & & & & & & & \\
\hline$\triangle$ OIL PRICE & 0.480 & 0.088 & 1.000 & & & & & & \\
\hline $\begin{array}{l}\text { EXCESS RE- } \\
\text { SERVES }\end{array}$ & 0.081 & 0.282 & 0.036 & 1.000 & & & & & \\
\hline$\triangle \mathrm{REER}$ & 0.365 & -0.003 & 0.025 & 0.023 & 1.000 & & & & \\
\hline CORRUPTION & 0.134 & 0.347 & -0.005 & 0.026 & -0.002 & 1.000 & & & \\
\hline POLITY & 0.114 & 0.387 & 0.007 & 0.117 & -0.020 & 0.191 & 1.000 & & \\
\hline $\begin{array}{l}\text { RENTx } \\
\text { CORRUPTION }\end{array}$ & 0.226 & 0.938 & 0.071 & 0.251 & -0.012 & 0.495 & 0.378 & 1.000 & \\
\hline RENTxPOLITY & 0.191 & 0.758 & 0.053 & 0.172 & -0.022 & 0.243 & 0.693 & 0.720 & 1.000 \\
\hline
\end{tabular}




\section{Methodology}

\subsection{The random effects panel Logit Model}

Unlike Aizenman and Glick (2009) [? ] and Carpantier and Vermeulen (2014) [9] who estimate the determinants of the SWF creation using a Logit model with cross-section data, we estimate a panel Logit model with random effects. The panel dimension in the model allows to take into account two central aspects : i) the temporal dimension that is necessary for explaining the number of created funds by year in our sample; ii) the unobserved heterogeneity between the different SWFs. This hypothesis is fundamental because SWFs form a heterogeneous group of investors, explained with respect to the various sources of their funds, their size in terms of assets under management, their organisational structure, their governance and their assigned objectives. In the same way, the inclusion of random effects in the panel model allows to control for omitted variables. ${ }^{15}$

Let us consider $y_{i t}$ an observed dependent variable representing the decision to create a SWF in country $i(i=1, \ldots, n)$ the year $t(t=1, \ldots, T)$.

The model is then :

$$
\begin{gathered}
y_{i t} *=\boldsymbol{x}_{i t} \beta+c_{i}+u_{i t}, \\
\operatorname{Pr}\left(y_{i t}=1 \mid x_{i t}, c_{i}\right)=\Lambda\left(x_{i t} \beta+c_{i}\right)
\end{gathered}
$$

where $y_{i t}=1$ if $y_{i t} *>0$ and 0 otherwise, $\boldsymbol{x}_{i t}$ is a $1 \mathrm{xK}$ vector of observed explanatory variables, $\boldsymbol{\beta}$ is a $\mathrm{Kx} 1$ vector of parameters, $c_{i}$ is an unobserved time invariant individual effect, $u_{i t}$ is an idiosyncratic error term and $\Lambda$ the logistic cumulative density function. ${ }^{16}$

\subsection{Panel unit root tests}

As we run a panel Logit model, we checked the stationarity of macroeconomic variables performing the Im, Pesaran and Shin (2003) [21] (IPS, henceforth) and the Pesaran (2007) [30] (CIPS*, henceforth) panel unit root tests. The IPS test is based on the mean of the individual countries ADF statistics. The CIPS test is the cross-sectionally augmented panel unit root test (CIPS) truncated to avoid excessive influences of extreme outcomes. The IPS test does not allow for cross-country dependence, whereas the CIPS test does. For both tests, the null hypothesis is that the series has a unit root for all countries in the panel against the alternative that for at least one country the series is stationary. The results of these tests are presented in Table 6 . We observe that the two tests considered reject the null hypothesis at the $1 \%$ level of significance for all variables - with $\log G D P$ and $R E E R$ and OILPRICE taken in difference, which means that all the variables of the model are well stationary.

15. In order to discriminate between fixed or random effects, we run the Hausman test. The results (available on request) show that the random effects model is preferred because it is a more efficient estimator.

16. The choice of a random effects panel model requires strong assumptions about the unobserved heterogeneity : it means that $c_{i}$ is unrelated to $x_{i t}$, so that the conditional distribution $f\left(c_{i} \mid x_{i t}\right)$ is not dependent on $x_{i t}(i=1, \ldots, 90)$ 
Table 6: Panel Unit Root Tests

\begin{tabular}{lrrrrr}
\hline Variable & IPS p-value & & CIPS statistics & \\
\hline$\Delta \log$ GDP & 0.000 & $* * *$ & -2.672 & $* * *$ \\
RENT & 0.000 & $* * *$ & -2.610 & $* * *$ \\
$\Delta$ REER & 0.000 & $* * *$ & -3.358 & $* * *$ \\
$\Delta$ OILPRICE & 0.000 & $* * *$ & -2.600 & $* * *$ \\
\hline
\end{tabular}

CIPS Critical values : significant at 10\%: -2.15 ; significant at $5 \%:-2.25$; significant at $1 \%:-2.42$ ${ }^{*}$ significant at $10 \% ;{ }^{* *}$ significant at $5 \% ; * * *$ significant at $1 \%$.

\section{Results}

\subsection{General model}

Results of the panel random effects Logit model for all countries are given in Table 7. The left-hand side variable in equation (1) is a dummy variable equal to one if the country $i$ $(i=1, \ldots ., 90)$ decided to establish one or several SWFs in year $t(t=2000, \ldots, 2014)$ and zero otherwise. ${ }^{17}$ The right-hand side variables are the potential determinants of the SWF's emergence over the period. In the first column we include all the possible explanatory variables, corresponding to the complete model. Because of the correlation between some variables, we then report different restricted versions of this model (columns (2) to (7)). Statistical inference is done with the Wald test in order to compare these restricted models to the complete model. For each model, statistical inference is done from the complete model using the Wald test based on a robust estimation of the variance-covariance matrix in order to test the joint significance of the explanatory variables. Robust standard errors are calculated for all regressions.

First, we find that the probability of establishing a SWF is positively related to excess foreign exchange reserves corresponding to Hypothesis 1. As our proxy of excess foreign exchange reserves is a dummy variable equal to 1 if the ratio of international reserves to short-term external debt is above $100 \%$ and 0 otherwise, this result suggests that a country will decide to establish a fund if its short-term external debt has been considerably reduced and/or if there is a source of increasing reserves (due to the discovery of a new natural resource for example). Related to this result, we find unsurprisingly that the ownership of natural resources rents is an important determinant of the SWF's creation (model (3)). At last, we also find that the probability to create a fund is positively related to the country's wealth (The variable $\Delta \log G D P$ is positive and significant at a level of $10 \%$ in model (2)). These results are also in line with the conclusions of Aizenman and Glick, (2009) [? ] and Carpantier and Vermeulen (2014) [9].

Secondly, the volatility of natural resource prices and more precisely the variations of oil prices affect positively the probability of setting up a SWF. This confirms our Hypothesis 2

17. This means that the dummy variable is equal to zero if the country did not create a fund over the period 2000-2014 or already created one before 2000. This implicitly assumes that the decision to establish a SWF over the considered period is independent from the fact that the country has already a SWF. 
according to which a country can decide to save a share of the gains from the boom of commodity prices in a sovereign wealth fund aimed at stabilizing the fiscal impact of fluctuating commodity prices and smoothing boom or bust cycles. This counter-cyclical role in relation to commodity world prices is particularly important when the economy of the country is dependent on commodity exportations. We will test hereafter if this result is particularly true for commodity funds and for stabilization funds, which aim at fighting against the volatility of natural resource prices.

Thirdly, Table 7 shows that the real effective exchange rate (REER) is significantly positive. As previously evoked, the oil production can generate significant windfalls in terms of export earnings, which can cause inflationary pressures and an appreciation of the local currency, a phenomenon known as the Dutch Disease. A SWF that invests the proceeds from natural resources and fiscal surplus wholly abroad can mitigate the Dutch Disease phenomenon and related macroeconomic consequences thanks to the diversification effect. Our result suggests that the probability of setting up a fund increases for countries knowing an appreciation of the real exchange rate in the short run, which is consistent with our Hypothesis 3. The distinction between commodity and non-commodity funds done hereafter will allow to test whether this result is particularly true for resource-rich countries.

Regarding Hypothesis 4 which stresses that countries with low democratic political institutions should be more likely to have SWFs, we find that the decision of setting up a SWF for a country has a political dimension. More precisely, the variable CORRUPTION as well as both interaction variables $((R E N T \times P O L I T Y)$ and $(R E N T \times C O R R U P T I O N))$ are positively significant, which means that the probability of setting up a SWF increases for corrupted countries, and more precisely for resource-rich countries with low governance (low level of democracy and high level of corruption). This result is consistent with $H 4$ and with the results found by Aizenman and Glick, 2009 [? ] and Carpantier and Vermeulen, 2014 [9] according to which country's governance is related to the establishment of a SWF.

\subsection{Some refinements on the dependent variable}

In order to take into account differences among SWFs, we have refined the dependent variable in two ways. First this variable was split into two components : i) a dummy variable equal to one if the country $i(i=1, \ldots ., 90)$ decided to establish a commodity-based SWF in year $t(t=2000, \ldots, 2014)$ and zero otherwise; ii) a dummy variable equal to one if the country $i(i=1, \ldots ., 90)$ decided to establish a non-commodity-based SWF in year $t$ $(t=2000, \ldots, 2014)$ and zero otherwise. This distinction allows to test whether the potential determinants of the SWF's creation are the same for commodity and non-commodity-based funds. Secondly, we split the dependent variable into three dummy variables depending on the SWFs objectives, namely a dummy variable for macroeconomic stabilization and saving funds; one for reserve investment funds and at last a dummy for domestic economic support funds. Table 8 provides the results of the panel random effects Logit model respectively for commodity-based funds and non-commodity-based funds and Table 9 displays the results for SWFs categorized according to their objectives. 
Unsurprisingly, we find that natural resources rents are a key determinant of the creation of commodity-based funds, while excess foreign exchange reserves play a clear role on the emergence of non-commodity-based funds. Interestingly, consistent with our previous result for all SWFs, Table 8 shows a positive significant relation between the creation of commodity-based funds and the volatility of oil prices (Panel B), which is not the case for non-commodity-based funds (Panel C). This is particularly the case for stabilization/saving funds as shown in Table 9 (Panel D), whose primary aim is to attempt insulating the economy from excess volatility in commodity prices. In the early 2000s, increasing oil prices brought about a massive redistribution of income to oil exporting countries, resulting in current account surpluses and foreign exchange reserves in excess. These oil-exporting countries decided to establish new SWFs in order to manage the accumulation of foreign exchange reserves and to safeguard the economy from boom-bust cycles. Examples include the Revenue Regulation Fund of Algeria, the Oil Revenue Stabilization Fund of Mexico, the National Investment Corporation of Kazakhstan or Heritage and Stabilization Fund of Trinidad and Tobago created in 2000 with, for all these funds, an objective of macroeconomic stabilization. Other examples of SWFs creations with the same objective during the oil price spike in 2007-2008 are among others the National Welfare Fund of Russia and the reserve Fund for Oil of Angola.

Once again, we find some evidence that the real effective exchange rate is a determinant of the creation of a SWF when we do the distinction between commodity and non-commoditybased fund. In particular, the positive significant relationship between the REER and the creation of commodity-based funds is confirmed by the data (Panel B). Our results show that resource-rich countries knowing Dutch Disease (appreciation of the REER and related macroeconomic consequences due to the diversification effect) are more likely to establish a commodity-based fund. The aim of such a fund is to invest the proceeds from natural resources and fiscal surplus wholly abroad in order to reduce the appreciation of the REER and therefore to mitigate the Dutch Disease effects. ${ }^{18}$ Results in Table 9 show that this significant positive relationship between REER and the creation of a SWF is confirmed whatever the objectives assigned to the fund.

Interestingly, the distinction of funds according to their objectives brings to the forefront the political dimension in the decision to create a SWF. In particular, we find in Table 9 that POLICY is highly significant for reserve investment funds. This suggests that these types of funds whose primary aim is to transform non-renewable resources into financial assets, are more likely to be created in countries with a low governance. Some examples of reserve investments funds created in countries with low governance are Abu Dhabi Investment Council, Qatar Investment Authority, Nigeria Sovereign Investment Authority, Fondo Soberano de

18. Although beyond the scope of the paper, the obtained results would have been strengthened by a more complete analysis of the Dutch Disease mechanism. In particular, we do not provide a specific test regarding the Dutch Disease hypothesis because both economic and institutional variables are used in our model as explanatory variables for explaining the decision of creating a SWF. The short and long run effects of natural resources rents on the REER may be appropriate and the effect on the manufacturing sector productivity could be taken into account. See Beine et al. (2016) [6] for an empirical analysis on the short and long-run impact of natural resources rents on the REER. 
Angola or Oman Investment Fund. In the same way, our results provide evidence (at a level of $10 \%$ however) that domestic support funds aimed at supporting the domestic economy are more likely to be created in countries with high level of corruption. 
Table 7: Logit Panel Model with Random Effects : All SWFs

This table reports results for the panel Logit model with random effects and robust errors considering all countries. The endogenous variable $(S W F$ $D U M M Y$ ) is a country dummy variable equals to 1 if the country established at least one fund in year $t$ and 0 otherwise. In the first column we include all the possible explanatory variables, corresponding to the complete model. Because of the correlation between some variables, we then report different restricted versions of this model (columns (2) to (7)). Statistical inference is done with the Wald test in order to compare these restricted models to the complete model. For each model, statistical inference is done from the complete model using the Wald test based on a robust estimation of the variance-covariance matrix in order to test the joint significance of the explanatory variables. Robust standard errors are calculated for all regressions.

\begin{tabular}{|c|c|c|c|c|c|c|c|c|c|c|c|c|c|c|}
\hline \multirow[b]{3}{*}{ Constant } & \multicolumn{14}{|c|}{ PANEL A } \\
\hline & \multicolumn{2}{|l|}{$(1)$} & \multicolumn{2}{|l|}{$(2)$} & \multicolumn{2}{|l|}{$(3)$} & \multicolumn{2}{|c|}{$(4)$} & \multicolumn{2}{|c|}{$(5)$} & \multicolumn{2}{|c|}{$(6)$} & \multicolumn{2}{|c|}{$(7)$} \\
\hline & -4.587 & $* * *$ & -4.071 & $* * *$ & -4.202 & $* * *$ & -4.475 & $* * *$ & -4.052 & $* * *$ & -4.159 & $* * *$ & -4.063 & $* * *$ \\
\hline & {$[0.536]$} & & {$[0.290]$} & & {$[0.310]$} & & {$[0.486]$} & & {$[0.303]$} & & {$[0.313]$} & & {$[0.284]$} & \\
\hline \multirow[t]{2}{*}{ EXCESS RESERVES } & 0.769 & $* *$ & 0.931 & $* * *$ & 0.733 & * & 0.960 & $* * *$ & 0.941 & $* * *$ & 0.760 & $* *$ & 0.851 & $* *$ \\
\hline & {$[0.372]$} & & {$[0.358]$} & & {$[0.389]$} & & {$[0.349]$} & & {$[0.349]$} & & {$[0.379]$} & & {$[0.360]$} & \\
\hline \multirow[t]{2}{*}{$\triangle O I L P R I C E$} & 0.026 & $* *$ & 0.023 & * & 0.028 & $* *$ & 0.031 & $* * *$ & 0.031 & $* * *$ & 0.029 & $* * *$ & 0.030 & $* * *$ \\
\hline & {$[0.013]$} & & {$[0.012]$} & & {$[0.011]$} & & {$[0.011]$} & & {$[0.011]$} & & {$[0.011]$} & & {$[0.011]$} & \\
\hline \multirow[t]{2}{*}{$\triangle R E E R$} & 0.023 & $* *$ & 0.021 & $* *$ & 0.026 & $* * *$ & 0.025 & $* *$ & 0.027 & $* * *$ & 0.026 & $* * *$ & 0.028 & $* * *$ \\
\hline & {$[0.010]$} & & {$[0.010]$} & & {$[0.009]$} & & {$[0.010]$} & & {$[0.010]$} & & {$[0.009]$} & & {$[0.010]$} & \\
\hline \multirow[t]{2}{*}{$\Delta \log G D P$} & 1.934 & & 4.775 & $*$ & & & & & & & & & & \\
\hline & {$[2.948]$} & & {$[2.563]$} & & & & & & & & & & & \\
\hline \multirow[t]{2}{*}{ RENT } & 0.018 & & & & 0.020 & $* * *$ & & & & & & & & \\
\hline & {$[0.026]$} & & & & {$[0.008]$} & & & & & & & & & \\
\hline \multirow[t]{2}{*}{ CORRUPTION } & 0.629 & & & & & & 0.751 & * & & & & & & \\
\hline & {$[0.531]$} & & & & & & {$[0.452]$} & & & & & & & \\
\hline \multirow[t]{2}{*}{ POLITY } & -0.158 & & & & & & & & 0.362 & & & & & \\
\hline & {$[0.531]$} & & & & & & & & {$[0.326]$} & & & & & \\
\hline \multirow[t]{2}{*}{$C O R R U P T I O N \times R E N T$} & -0.010 & & & & & & & & & & 0.019 & $* *$ & & \\
\hline & {$[0.025]$} & & & & & & & & & & {$[0.007]$} & & & \\
\hline \multirow[t]{2}{*}{$P O L I T Y \times R E N T$} & 0.009 & & & & & & & & & & & & 0.017 & $* *$ \\
\hline & {$[0.016]$} & & & & & & & & & & & & {$[0.008]$} & \\
\hline Log-likelihood & -195.0 & & -198. & & -196. & & -197.2 & & -198. & & -196. & & -197. & \\
\hline Wald chi2 & 11.70 & & 5.47 & & 3.07 & & 6.18 & & 10.55 & & 3.19 & & 5.00 & \\
\hline Degree of freedom & $(6)$ & & $(5)$ & & $(5)$ & & $(5)$ & & $(5)$ & & $(5)$ & & $(5)$ & \\
\hline p-value & 0.0689 & $*$ & 0.3611 & & 0.689 & & 0.289 & & 0.061 & & 0.671 & & 0.417 & \\
\hline
\end{tabular}

* Significant at $10 \% ;{ }^{* *}$ significant at $5 \% ;{ }^{* * *}$ significant at $1 \%$. Robust standard-errors are between brackets. 
Table 8: Logit Panel Model with Random Effects : Commodity-based SWFs and NonCommodity-based SWFs

This table reports results for the panel Logit model with random effects and robust errors by considering Commodity-based SWFs (PANEL B) and Non-commodity-based SWFs (PANEL C). In models (1) and (2), the endogenous variable is a country dummy variable equal to 1 if the country established at least one SWF funded mainly from oil exports, gas or other minerals in year $t$ and 0 otherwise. The endogenous variable in models (3) and (4) is a country dummy variable equal to 1 if the country established at least one SWF funded by the transfer of assets from both government budget surpluses and foreign reserve excess in year $t$ and 0 otherwise. Columns (1) and (3) report the results of the complete models while columns (2) and (4) report the results of the parsimonious models.

\begin{tabular}{|c|c|c|c|c|c|c|c|c|}
\hline & \multicolumn{4}{|c|}{ PANEL B } & \multicolumn{4}{|c|}{ PANEL C } \\
\hline & \multicolumn{2}{|c|}{ (1) } & \multicolumn{2}{|c|}{$(2)$} & \multicolumn{2}{|c|}{$(3)$} & \multicolumn{2}{|c|}{$(4)$} \\
\hline \multirow[t]{2}{*}{ Constant } & -5.297 & $* * *$ & -5.236 & $* * *$ & -5.419 & $* * *$ & -5.202 & $* * *$ \\
\hline & {$[0.651]$} & & {$[0.470]$} & & {$[0.713]$} & & {$[0.687]$} & \\
\hline \multirow[t]{2}{*}{ EXCESS RESERVES } & 0.463 & & & & 1.156 & $* *$ & 1.226 & $* *$ \\
\hline & {$[0.497]$} & & & & {$[0.518]$} & & {$[0.527]$} & \\
\hline \multirow[t]{2}{*}{$\triangle O I L P R I C E$} & 0.030 & $* *$ & 0.031 & $* *$ & 0.019 & & & \\
\hline & {$[0.015]$} & & {$[0.014]$} & & {$[0.019]$} & & & \\
\hline \multirow[t]{2}{*}{ RENT } & 0.038 & $* * *$ & 0.040 & $* * *$ & -0.027 & $*$ & -0.025 & * \\
\hline & {$[0.012]$} & & {$[0.008]$} & & {$[0.014]$} & & {$[0.014]$} & \\
\hline \multirow[t]{2}{*}{$\triangle R E E R$} & 0.022 & $* *$ & 0.019 & $* *$ & 0.022 & $*$ & 0.022 & $* *$ \\
\hline & {$[0.010]$} & & {$[0.009]$} & & {$[0.011]$} & & {$[0.011]$} & \\
\hline \multirow[t]{2}{*}{$\Delta \log G D P$} & 0.516 & & & & 2.670 & & & \\
\hline & {$[3.333]$} & & & & {$[3.652]$} & & & \\
\hline \multirow[t]{2}{*}{ CORRUPTION } & -0.065 & & & & 1.236 & $*$ & 1.256 & $*$ \\
\hline & {$[0.639]$} & & & & [0.654] & & {$[0.657]$} & \\
\hline \multirow[t]{2}{*}{ POLITY } & 0.081 & & & & 0.004 & & & \\
\hline & {$[0.495]$} & & & & {$[0.479]$} & & & \\
\hline Log-likelihood & -124.709 & & -129.673 & & -97.569 & & -98.759 & \\
\hline Wald chi2 & & & 0.92 & & & & 2.01 & \\
\hline Degree of freedom & & & (4) & & & & (3) & \\
\hline p-value & & & 0.922 & & & & 0.571 & \\
\hline
\end{tabular}

* Significant at $10 \% ;{ }^{* *}$ significant at $5 \% ; * * *$ significant at $1 \%$. Robust standard-errors are between brackets. 
Table 9: Logit Panel Model with Random Effects - Panel D to F

This table reports results for the panel Logit model with random effects and robust errors by considering SWFs according to their objectives. In models (1) and (2) (PANEL D), the endogenous variable (MACROSTAB $\times S A V I N G)$ is a country dummy variable equal to one if the country established at least one macrostabilisation or saving SWF in year $t$ and 0 otherwise. In models (3) and (4) (PANEL E), the endogenous variable (RESERVEFUND) is a country dummy variable equal to one if the country established at least one reserve investment SWF in year $t$ and 0 otherwise. In models (5) and (6) (PANEL F), the endogenous variable (DOMESTICSU PPORT) is a country dummy variable equal to one if the country established at least one SWF with the aim to support domestic economy in year $t$ and 0 otherwise.

\begin{tabular}{|c|c|c|c|c|c|c|c|c|c|c|c|c|}
\hline & \multicolumn{4}{|c|}{ Panel D } & \multicolumn{4}{|c|}{ Panel E } & \multicolumn{4}{|c|}{ Panel F } \\
\hline & \multicolumn{2}{|l|}{$(1)$} & \multicolumn{2}{|l|}{$(2)$} & \multicolumn{2}{|l|}{ (3) } & \multicolumn{2}{|l|}{ (4) } & \multicolumn{2}{|c|}{$(5)$} & \multicolumn{2}{|c|}{ (6) } \\
\hline \multirow[t]{2}{*}{ Constant } & -5.149 & *** & -5.372 & $* * *$ & -6.528 & $* * *$ & -6.816 & $* * *$ & -5.806 & $* * *$ & -5.717 & $* * *$ \\
\hline & [0.594] & & {$[0.500]$} & & [0.996] & & {$[0.774]$} & & {$[0.866]$} & & {$[0.803]$} & \\
\hline \multirow[t]{2}{*}{ EXCESS RESERVES } & 0.326 & & & & 1.392 & * & 1.245 & * & 0.059 & * & 1.147 & $* *$ \\
\hline & {$[0.481]$} & & & & {$[0.727]$} & & {$[0.673]$} & & {$[0.512]$} & & {$[0.475]$} & \\
\hline \multirow[t]{2}{*}{$\triangle O I L P R I C E$} & 0.036 & * & 0.042 & $* *$ & 0.020 & & 0.027 & * & 0.028 & & & \\
\hline & {$[0.019]$} & & {$[0.017]$} & & {$[0.022]$} & & {$[0.015]$} & & {$[0.022]$} & & & \\
\hline \multirow[t]{2}{*}{ RENT } & 0.031 & $* *$ & 0.026 & $* *$ & 0.009 & & & & 0.014 & & & \\
\hline & {$[0.014]$} & & {$[0.011]$} & & {$[0.016]$} & & & & {$[0.012]$} & & & \\
\hline \multirow[t]{2}{*}{$\triangle R E E R$} & 0.023 & $* *$ & 0.025 & ** & 0.029 & * & 0.034 & $* * *$ & 0.025 & ** & 0.022 & $* *$ \\
\hline & {$[0.011]$} & & {$[0.011]$} & & {$[0.015]$} & & {$[0.011]$} & & {$[0.011]$} & & {$[0.010]$} & \\
\hline \multirow[t]{2}{*}{$\Delta \log G D P$} & 2.368 & & & & 5.271 & & & & -3.072 & & & \\
\hline & [4.638] & & & & [5.343] & & & & {$[3.657]$} & & & \\
\hline \multirow[t]{2}{*}{ CORRUPTION } & -0.322 & & & & $(\text { omitted })^{\star}$ & & $(\text { omitted })^{\star}$ & & 1.353 & & 1.425 & * \\
\hline & {$[0.616]$} & & & & $(\text { omitted })^{\star}$ & & $(\text { omitted })^{\star}$ & & {$[0.761]$} & & {$[0.745]$} & \\
\hline \multirow[t]{2}{*}{ POLITY } & -0.437 & & & & 1.992 & *** & 2.102 & $* * *$ & -0.492 & & & \\
\hline & {$[0.558]$} & & & & {$[0.731]$} & & {$[0.794]$} & & {$[0.521]$} & & & \\
\hline Log-likelihood & -110.137 & & -112.086 & & -47.553 & & -50.740 & & -95.954 & & -97.956 & \\
\hline Wald chi2 & & & 1.13 & & 8.85 & & 1.05 & & & & 3.37 & \\
\hline Degree of freedom & & & (4) & & (3) & & (2) & & & & (4) & \\
\hline p-value & & & 0.890 & & & & 0.590 & & & & 0.498 & \\
\hline
\end{tabular}

* Significant at $10 \%$; $^{* *}$ significant at $5 \%$; ${ }^{* *}$ significant at $1 \%$. Robust standard-errors are between brackets.

* This variable is omitted because, as it is a dummy variable equal to 1 for all Reserve Funds, there is no variability in this variable. 


\subsection{Marginal Effects of explanatory variables}

In order to interpret the size of the effects, we estimate conditional marginal effects of significant variables for Panel A (or marginal effects at the means), which are marginal effects when all other variables are at their mean. ${ }^{19}$ These results are presented in table 10. For binary explanatory variables (EXCESS RESERVES and CORRUPTION), marginal effects show how $\mathrm{P}(\mathrm{SWF}=1)$ changes when the categorical variables vary from 0 to 1 , holding all other variables at their means. For continuous explanatory variables, marginal effects measure the instantaneous rate of change of $\mathrm{P}(\mathrm{SWF}=1)$, holding all other variables at their means.

Our results show that the marginal effects are significant for all the variables, suggesting that these variables are well related to the establishment of a fund. The coefficient on income per capita indicates that an infinitesimal variation of the $\triangle \log G D P$ increases the probability to create a fund from 0.13 , holding all other variables at their means. In the same way, we find that the probability of the SWF creation increases by more than 0.02 and 0.017 respectively for countries having excess foreign exchange reserves and knowing corruption. The effects of the other variables are smaller.

\section{Table 10: Conditional Marginal Effects}

This table reports Conditional Marginal effects for the panel Logit models with random effects and robust errors considering all countries presented in Table 7. Conditional Marginal Effects, also called Marginal Effects at the Means, are the Marginal Effects when all other variables equal their means. With binary independent variables (EXCESS RESERVES and CORRUPTION), the marginal effects show how $P(S W F=1)$ changes when the categorical variable varies from 0 to 1 , holding all other variables at their means. For continuous variables, the marginal effect measures the instantaneous rate of change of $P(S W F=1)$. In this case, $d y / d x$ gives the change in probability for a country to create a SWF for an infinitesimal increase of the variable, holding all other variables at their means.

\begin{tabular}{|c|c|c|c|c|c|c|c|c|c|c|}
\hline & (1) & & $(2)$ & & (3) & & (4) & & (5) & \\
\hline EXCESS RESERVES & $\begin{array}{r}0.0338 \\
{[0.0169]}\end{array}$ & $* *$ & $\begin{array}{r}0.0238 \\
{[0.0157]}\end{array}$ & & $\begin{array}{r}0.0341 \\
{[0.0096]}\end{array}$ & $* *$ & $\begin{array}{r}0.0250 \\
{[0.0157]}\end{array}$ & & $\begin{array}{r}0.0291 \\
{[0.0161]}\end{array}$ & $*$ \\
\hline$\triangle O I L P R I C E$ & $\begin{array}{r}0.0006 \\
{[0.0003]}\end{array}$ & $*$ & $\begin{array}{r}0.0007 \\
{[0.0003]}\end{array}$ & $* *$ & $\begin{array}{r}0.0008 \\
{[0.0003]}\end{array}$ & $* * *$ & $\begin{array}{r}0.0007 \\
{[0.0003]}\end{array}$ & $* *$ & $\begin{array}{r}0.0008 \\
{[0.0003]}\end{array}$ & *** \\
\hline$\triangle R E E R$ & $\begin{array}{r}0.0006 \\
{[0.0003]}\end{array}$ & $* *$ & $\begin{array}{r}0.0007 \\
{[0.0002]}\end{array}$ & $* * *$ & $\begin{array}{r}0.0006 \\
{[0.0003]}\end{array}$ & $* *$ & $\begin{array}{r}0.0007 \\
{[0.0002]}\end{array}$ & $* * *$ & $\begin{array}{r}0.0007 \\
{[0.0003]}\end{array}$ & $* * *$ \\
\hline$\Delta \log G D P$ & $\begin{array}{r}0.1266 \\
{[0.0712]}\end{array}$ & $*$ & & & & & & & & \\
\hline RENT & & & $\begin{array}{r}0.0005 \\
{[0.0002]}\end{array}$ & $* *$ & & & & & & \\
\hline CORRUPTION & & & & & $\begin{array}{r}0.0173 \\
{[0.0043]}\end{array}$ & $* *$ & & & & \\
\hline$C O R R U P T I O N \times R E N T$ & & & & & & & $\begin{array}{r}0.0005 \\
{[0.0002]}\end{array}$ & $* *$ & & \\
\hline$P O L I T Y \times R E N T$ & & & & & & & & & $\begin{array}{r}0.0004 \\
{[0.0002]}\end{array}$ & $* *$ \\
\hline
\end{tabular}

* Significant at $10 \% ;{ }^{* *}$ significant at $5 \% ;{ }^{* * *}$ significant at $1 \%$. Robust standard-errors are between brackets.

19. Average Marginal Effects have also been calculated. The results are close to the Marginal Effects at the Means and are available upon request. 


\section{Conclusion}

This paper aims to shed light on the question of why a country decides to set up a SWF. Using theories relative to optimal policy of investments and savings in resource-rich countries and/or in countries with foreign exchange reserves, we tested the economic, political and institutional country factors explaining the decision to establish a SWF. More precisely, we tested if the establishment of a SWF can be explained by the following factors : 1) the excess foreign exchange reserves due to natural resources rents or persistent current account surpluses ; 2) the volatility of commodity prices ; 3) a way to mitigate the "Dutch Disease" effect; 4) the governance of the country. In order to allow the temporal dimension as well as the unobserved heterogeneity between SWFs, a Logit panel model with random effects has been estimated.

Several insights emerge from our analysis. As in the papers of Aizenman and Glick (2009) [2] and Carpantier and Vermeulen (2014) [9], our results unsurprisingly show that the probability of setting up a fund is positively related to the country's wealth and to revenue inflows, i.e. excess foreign exchange reserves due to natural resources rents for resource-rich countries and current account surplus for non-commodity countries. It means that countries with large excess cash flows may allocate these funds to a SWF. We also find that the creation of commodity-based funds and more particularly stabilization/saving funds can be explained by the volatility of oil prices. The aim of these funds is to diversify the economic exposure of countries dependent on a single commodity like oil.

Interestingly, our empirical analysis provides some evidence of the Dutch Disease theory. In particular, our results show that resource-rich countries knowing an appreciation of the REER are more likely to establish a commodity-based fund. The aim of such a fund is to invest the proceeds from natural resources and fiscal surplus wholly abroad in order to reduce the appreciation of the REER and therefore to mitigate the Dutch Disease effect. Saving the proceeds abroad in a fund can therefore assist in mitigating Dutch Disease and related macroeconomic consequences, as proposed by Corden (2012) [12].

At last, we find that the decision of setting up a SWF for a country has not only an economic dimension but that it also has a political dimension. In particular, our results suggest that non-democratic countries with a high level of corruption are more more likely to create a SWF and these countries tend to prefer to establish a reserve investment fund whose primary aim is to transform non-renewable resources into financial assets.

As a whole, our results provide some explanation on why a country decides to create a SWF and may be of interest for policymakers debating whether or not it can be optimal for the country to establish a SWF. The question of whether the creation of a SWF is an efficient solution to manage excess foreign exchange reserves and therefore to mitigate the Dutch Disease effect but also to fight against corruption can be pursued in a further extended research. 
[1] Aizenman, J. (2007). Sovereign wealth funds : stumbling blocks or stepping stones to financial globalization?, FRBSF Economic Letter, 2007-38

[2] Aizenman, J. and R. Glick (2009). Sovereign wealth funds : stylized facts about their determinants and governance, International Finance, 12(3), 351-386.

[3] Al-Hassan A., Papaioannou M., Skancke M., Sung C. C. (2013). Sovereign wealth funds : aspects of governance structures and investment management, IMF Working Paper, 231.

[4] Beck, R. and M. Fidora (2008). The impact of sovereign wealth funds on global financial markets, Intereconomics, 349-358.

[5] Beine, M., Coulombe, S. and W.N. Vermeulen (2014). Dutch Disease and the mitigation effect of migration : evidence from Canadian provinces, The Economic Journal, 1271, $1-48$.

[6] Beine, M., R. Joyeux, C. Lecourt and J. Sheen (2016). Real effective exchange rate and resource rents : evidence in the short and long run, Working Paper.

[7] Blattman, C., J. Hwang and J.G. Williamson (2007). Winners and losers in the commodity lottery : The impact of terms of trade growth and volatility in the Periphery 1870-1939, Journal of Development Economics, 82, 156-179.

[8] Butt, S., A. Shivdasani, C. Stendevad, and A. Wyman (2008). Sovereign wealth funds : a growing force in corporate finance, Journal of Applied Corporate Finance 20, 73-83.

[9] Carpantier, J.F. and W.N. Vermeulen (2014). Emergence of sovereign wealth funds, Working Paper.

[10] Catalano, A. (2009). Property sector is well placed to attract wealth of nations, Sovereign wealth funds Special report, EG Capital.

[11] Chong, X.Y., Bahgat, G. (2016). The political economy of sovereign wealth funds, Palgrave Macmillan.

[12] Corden, M. (2012). The Dutch Disease in Australia : policy options for a three-speed economy, Melbourne Institute WP 5/12, February.

[13] Corden, W. M. and J.P. Neary (1982). Booming sector and De-industrialisation in a small open economy, The Economic Journal, 92, 825-848.

[14] Das, U. S., Lu, Y., Mulder, C. and A. Sy (2009). Setting up a sovereign wealth fund : some policy and operational considerations, IMF Working Paper, 179.

[15] Frankel, J.A. (2012). The natural resource curse : a survey of diagnoses and some prescriptions, Faculty Research Working Paper Series, Harvard Kennedy School, RWP12014.

[16] Fernandez, D. G. and Eschweiler, B. (2008). Sovereign Wealth Funds : A Bottom-up Primer, JP Morgan Research. 
[17] Fukuda, S.I. and Y. Kon (2010). Macroeconomic impacts of foreign exchange reserve accumulation : theory and evidence, ADBI Working Paper Series, 197.

[18] Gelb, A. (1988). Oil windfalls : blessing or curse?, World Bank Research Publication.

[19] Griffith-Jones, S. and J. A. Ocampo (2012). Sovereign wealth funds : a developing country perspective, K.P. Sauvant, L.E Sachs and Wouter P.F. Schmit Jongbloed (ed.), Sovereign investment : concerns and policy reactions, Oxford University Press.

[20] Hausmann, R. and R. Rigobon (2003). An alternative interpretation of the resource curse : theory and policy implications, Working Paper No. 9424, NBER, Cambridge, $M A$.

[21] Im, K.S., Pesaran, M.H. and Shin, Y. (2003). Testing for Unit Roots in heterogeneous Panels, Journal of Economics. 115, 53-74.

[22] IMF (2008). Sovereign wealth funds : a work agenda, IMF.

[23] Isham, J.L., Pritchett, M., Woolcock, M. and G. Busby (2003). The varieties of the resource experience : how natural resource export structures affect the political economy of economic growth?, Mimeo, World Bank, Washington D.C.

[24] Jeanne, O. (2007). International reserves in emerging market countries : too much of a good thing?, IMF Working Paper.

[25] Jeanne, O. and R. Ranciere (2006). The optimal level of international reserves for emerging market countries : formulas and applications, IMF Working Paper, 06/229.

[26] Kaldor, M, Karl, T.L. and Y. Said (2007). Oil wars, Pluto Press, edited by M. Kaldor.

[27] Kimmit, R.M. (2008). Public footprints in private markets, Foreign Affairs, 87, 1.

[28] Lyons, G. (2007). State capitalism : The rise of sovereign wealth funds, Journal of Management Research 7, Number 3, 119-146.

[29] Megginson, W.L. and V. Fotak (2015). Rise of the fiduciary state : a survey of sovereign wealth fund research, Journal of Economic Survey, 29, 4, 733-778.

[30] H. Pesaran, (2007). A Simple Panel Unit Root Test in the Presence of Cross Section Dependence, Journal of Applied Econometrics 22, 2, 265-312.

[31] Rodrick, D. (2006). The social cost of foreign exchange reserves, International Economic Journal, 20, 3, 253-266.

[32] Sachs, J.D. and A.M. Warner (1995). Natural resource abundance and economic growth, NBER Working Paper, 5398.

[33] Sachs, J.D. and A.M. Warner (2001). The curse of natural resources, European Economic Review, 45, 827-838. 
[34] Sala-i-Martin, X. and A. Subramanian (2003). Addressing the natural resource curse : an illustration from Nigeria, IMF Working Paper, 03/139.

[35] Smith, B. (2004). Oil wealth and regime survival in the developing world, 1960-1999, American Journal of Political Science, 48, 2, 232-246.

[36] Santiso, J. (2012). Sovereign wealth funds, ESADEgeo - Center for Global Economy and Geopolitics.

[37] Van der Ploeg, F. (2011). Natural Resources : Curse or Blessing, Journal of Economic Literature, 49(2), 366-420.

[38] Van der Ploeg, F, Poelhekke, S. (2009). Volatility and the natural resource curse, Oxford Economic Papers, 61, 4, 727-760. 
Appendix 1. List of SWFs

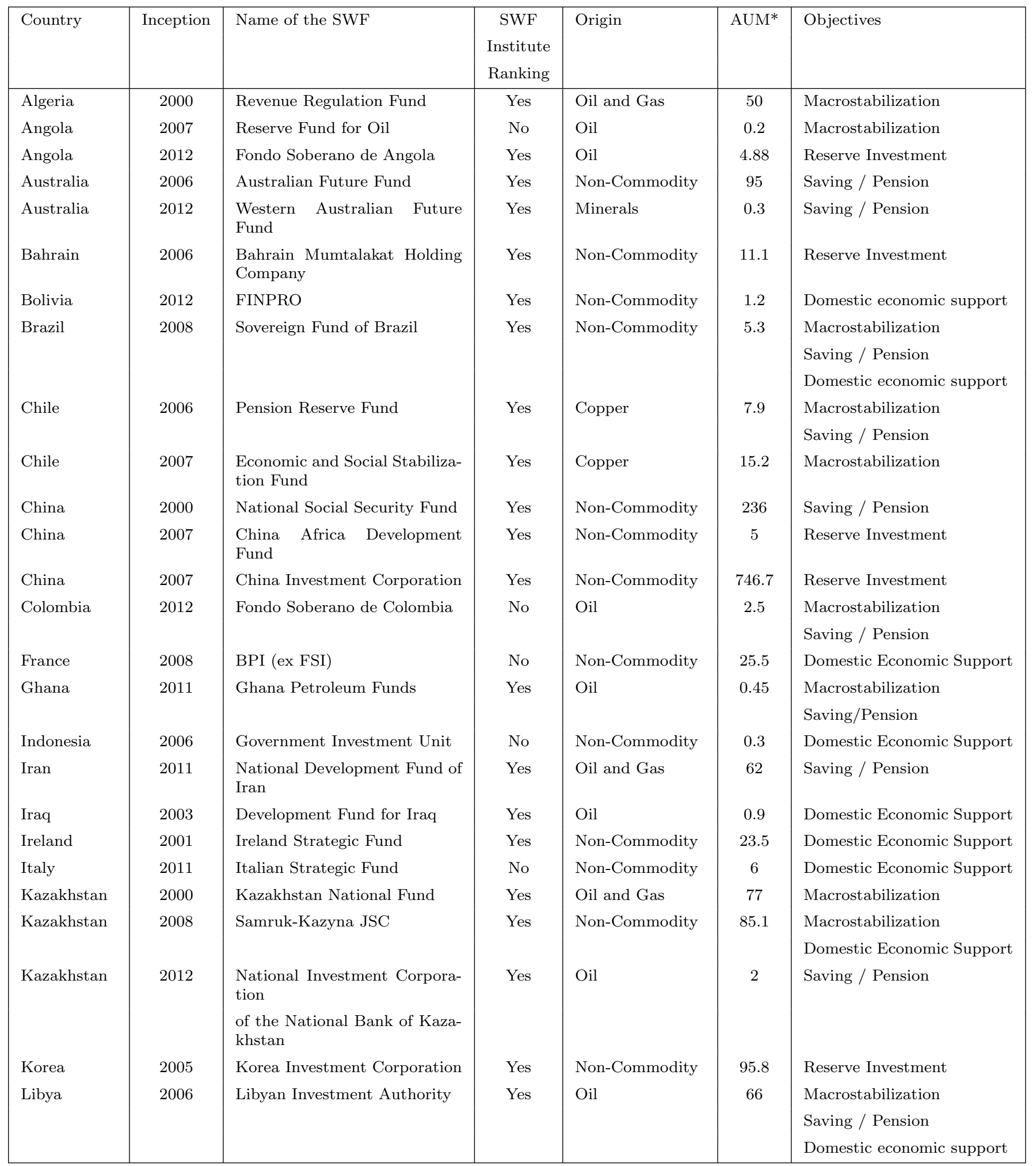




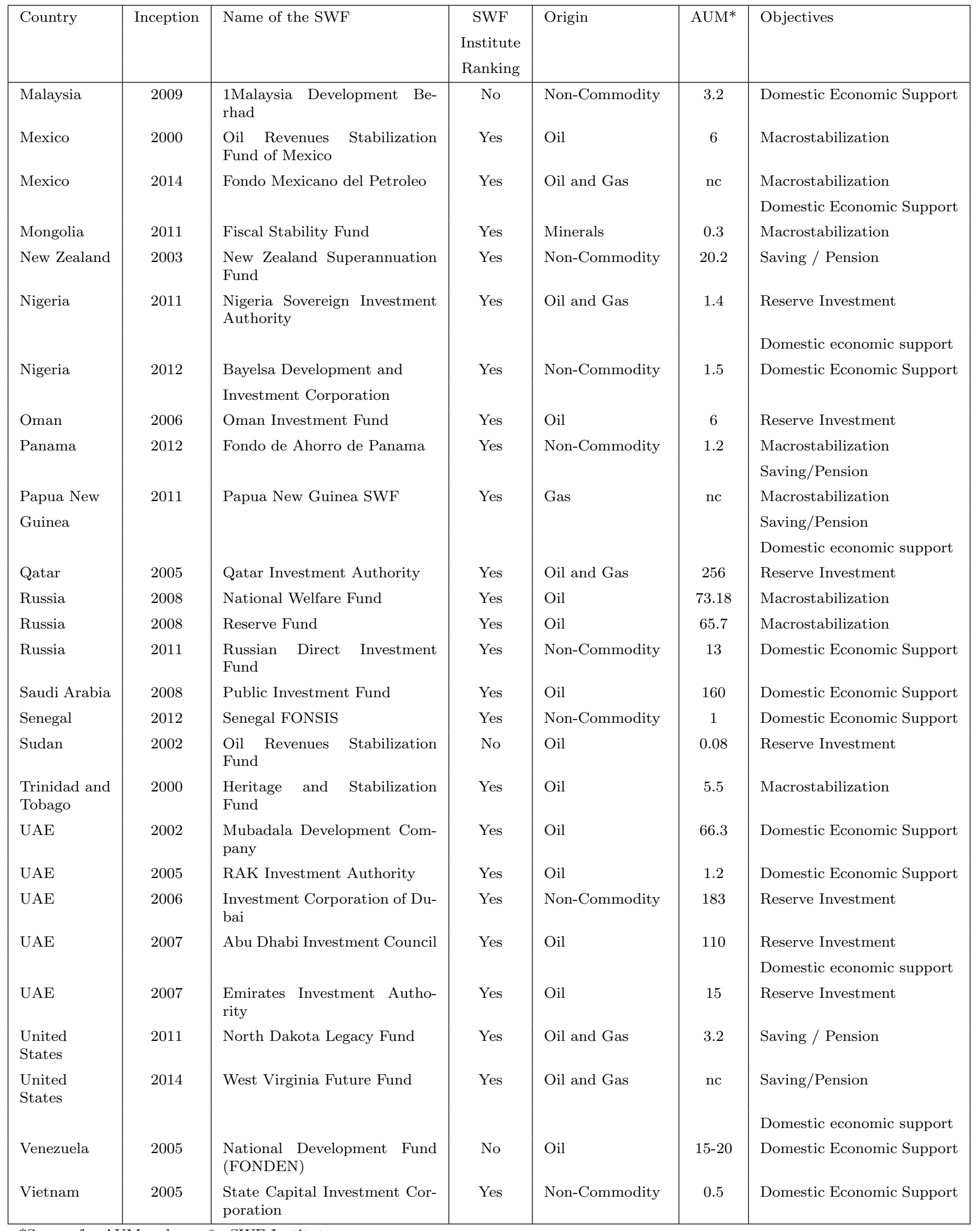

*Source for AUM, column 6 : SWF Institute 


\section{Appendix 2. Description of the variables}

\begin{tabular}{|c|c|c|}
\hline Variables & Description & Source \\
\hline SWF DUMMY & $\begin{array}{l}\text { Country dummy equal to } 1 \text { if the country established at least one fund } \\
\text { in year } t \text { and } 0 \text { otherwise }\end{array}$ & Authors' analysis \\
\hline COMMODITY SWF & $\begin{array}{l}\text { Country dummy equal to } 1 \text { if the country established at least one } \\
\text { SWF funded mainly from oil exports, gas or other minerals in year } t \\
\text { and } 0 \text { otherwise }\end{array}$ & Authors' analysis \\
\hline $\begin{array}{l}\text { NON-COMMODITY } \\
\text { SWF }\end{array}$ & $\begin{array}{l}\text { Country dummy equal to } 1 \text { if the country established at least one } \\
\text { SWF funded by the transfer of assets from both government budget } \\
\text { surpluses and excess foreign reserves in year } t \text { and } 0 \text { otherwise }\end{array}$ & Authors' analysis \\
\hline $\begin{array}{l}\text { MACROSTAB x SA- } \\
\text { VING }\end{array}$ & $\begin{array}{l}\text { Country dummy equal to } 1 \text { if the country established at least one } \\
\text { SWF with the aim to counterbalance commodity prices fluctuations } \\
\text { or create a reserve of wealth for the future in year } t \text { and } 0 \text { otherwise }\end{array}$ & Authors' analysis \\
\hline RESERVE FUND & $\begin{array}{l}\text { Country dummy equal to } 1 \text { if the country established at least one } \\
\text { SWF with the aim to maximize returns in year t and } 0 \text { otherwise }\end{array}$ & Authors' analysis \\
\hline $\begin{array}{l}\text { DOMESTIC SUP- } \\
\text { PORT }\end{array}$ & $\begin{array}{l}\text { Country dummy equal to } 1 \text { if the country established at least one } \\
\text { SWF with the aim support the domestic economy in year } t \text { and } 0 \\
\text { otherwise }\end{array}$ & Authors' analysis \\
\hline GDP & Gross domestic product in current U.S. dollars for year $t$ & The World Bank \\
\hline$\Delta \log G D P$ & Difference between $\log G D P_{t}$ and $\log G D P_{t-1}$ & \\
\hline RENT & $\begin{array}{l}\text { Sum of oil rents, natural gas rents, coal rents (hard and soft), mineral } \\
\text { rents, and forest rents expressed in percentage of GDP. }\end{array}$ & The World Bank \\
\hline EXCESS RESERVES & $\begin{array}{l}\text { Dummy variable that equals } 1 \text { if the ratio } R E S E R V E S / D E B T> \\
1 \text { and } 0 \text { otherwise. RESERVES is the total reserves including gold } \\
\text { expressed in current U.S. dollars. DEBT is the gross government debt- } \\
\text { to-GDP ratio }\end{array}$ & $\begin{array}{l}\text { The World Bank \& In- } \\
\text { ternational Monetary } \\
\text { Fund }\end{array}$ \\
\hline$\triangle$ OILPRICE & $\begin{array}{l}\text { Difference between the average crude oil prices of year } t \text { and the ave- } \\
\text { rage crude oil prices of year } t-1\end{array}$ & $\begin{array}{l}\text { International Mone- } \\
\text { tary Fund }\end{array}$ \\
\hline$\triangle \mathrm{REER}$ & $\begin{array}{l}\text { Difference between } R E E R_{t} \text { and } R E E R_{t-1} . R E E R_{t} \text { is the consumer } \\
\text { price index-based real effective exchange rate of year } t\end{array}$ & Bruegel database \\
\hline CORRUPTION & $\begin{array}{l}\text { Dummy variable that equals } 1 \text { if the ICRG corruption index is lo- } \\
\text { wer than } 3 \text { (the country is corrupted) and } 0 \text { otherwise. The ICRG } \\
\text { corruption index is an assessment of corruption within the political } \\
\text { system which ranges from } 0 \text { to } 6 \text {. The higher the index is, the lower } \\
\text { the country is corrupted }\end{array}$ & $\begin{array}{l}\text { International Country } \\
\text { Risk Guide (ICRG) }\end{array}$ \\
\hline POLITY & $\begin{array}{l}\text { Dummy variable that equals } 1 \text { if the Polity IV index is negative (the } \\
\text { country tends to be autocratic) and } 0 \text { otherwise. The Polity IV index } \\
\text { is an assessment of the level of authority of a regime. The index ranges } \\
\text { from }-10 \text { to } 10 \text {. The higher the index is, the more democratic is the } \\
\text { country }\end{array}$ & Polity IV Project \\
\hline RENT x POLITY & $\begin{array}{l}\text { Interaction variable between the polity dummy variable and the na- } \\
\text { tural resource rent }\end{array}$ & Authors' analysis \\
\hline $\begin{array}{l}\text { RENT } \quad x \quad \text { CORRUP- } \\
\text { TION }\end{array}$ & $\begin{array}{l}\text { Interaction variable between the corruption dummy variable and the } \\
\text { natural resource rent }\end{array}$ & Authors' analysis \\
\hline
\end{tabular}

